\title{
A systematic review of spleen and pancreas preservation in extended lymphadenectomy for gastric cancer
}

\author{
Savtaj S. Brar • Rajini Seevaratnam • \\ Roberta Cardoso - Calvin Law · Lucy Helyer • \\ Natalie Coburn
}

Received: 30 May 2011/ Accepted: 29 July 2011 / Published online: 14 September 2011

(C) The International Gastric Cancer Association and The Japanese Gastric Cancer Association 2011

\begin{abstract}
Background The overall prognosis and survival of patients with advanced gastric cancer are generally poor. Extended lymphadenectomy is recommended for patients with advanced gastric cancer; however, splenectomy and distal pancreatectomy performed with an extended lymph node dissection may be associated with increased morbidity and mortality.

Method Electronic literature searches were conducted using Medline, Embase, and the Cochrane Central Register of Controlled Trials from 1 January 1998 to 31 December 2009. Studies on gastric carcinoma investigating extended lymphadenectomy with splenectomy and/or pancreaticosplenectomy that reported data on surgical outcomes or survival were selected.

Results Forty studies were included in this review. Decreased complication rates were demonstrated with spleen preservation in two prospective studies and three
\end{abstract}

Electronic supplementary material The online version of this article (doi:10.1007/s10120-011-0087-4) contains supplementary material, which is available to authorized users.

\section{S. S. Brar · C. Law · N. Coburn ( ()}

Division of Surgical Oncology, Sunnybrook Health Sciences

Centre, Odette Cancer Centre, Suite T2-60, 2075 Bayview Ave,

Toronto, ON M4N-3M5, Canada

e-mail: natalie.coburn@sunnybrook.ca

\section{S. S. Brar}

The London School of Economics, London, UK

R. Seevaratnam $\cdot$ R. Cardoso $\cdot$ N. Coburn

Sunnybrook Research Institute, Sunnybrook Health Sciences

Centre, Toronto, Canada

L. Helyer

Department of Surgery, Dalhousie University, Halifax, Canada retrospective studies, and with pancreas preservation in five retrospective studies. No randomized controlled trial showed survival benefit or detriment for preservation of spleen or pancreas in extended lymphadenectomy. Improved survival was demonstrated with spleen preservation in two prospective and eight retrospective studies, and with pancreas preservation in one prospective and four retrospective studies.

Conclusions Preservation of the spleen and pancreas during extended lymphadenectomy for gastric cancer decreases complications with no clear evidence of improvement or detriment to overall survival.

Keywords Gastric cancer · Surgery · Lymphadenectomy $\cdot$ Spleen $\cdot$ Pancreas

\section{Introduction}

Adequate surgical resection remains the foundation of curative therapy for patients with gastric cancer. Lymphadenectomy is considered essential for gastric cancer surgery; however, the extent of lymph node removal is still debated in the literature [1-6]. In Asia, extended lymph node dissection has long been the standard of care for patients with advanced gastric cancer [7-10]. D2 lymphadenectomy, which includes recovery of the lymph nodes from along the splenic artery and the splenic hilum, is widely accepted in Asia as both safe and necessary. Spread of malignant cells to the nodes along the splenic artery and within the hilum has been reported to occur in a significant proportion of patients with gastric cancer and has been cited as a harbinger of poor prognosis $[8,11]$. Lymphogram imaging studies support the notion that gastric cancer in the proximal third of the stomach 
preferentially drains to the lymph nodes of the splenic artery and hilum [12]. Historically, 20-30\% of patients with proximal gastric cancer had metastases to the lymph nodes in the splenic hilum [13]. Distal gastric cancers, on the other hand, rarely have involvement of these lymph nodes [14]. The historical D2 lymphadenectomy included both splenectomy and distal pancreatectomy for adequate clearance of these nodes, and this approach was supported by early reports in the 1980s from the Japanese literature [14]. Furthermore, several authors state that resection of the spleen and pancreas may be necessary in patients with advanced disease, such as positive lymph nodes along the splenic artery [8, 14-18] or T3 disease [18-20]. However, resection of the spleen and distal pancreas is a technically demanding component of the extended lymphadenectomy and results in increased complications, especially pancreatic fistula [11, 14, 17, 21-23].

Two large multicenter randomized trials (RCTs), the Medical Research Council (MRC), Gastric Cancer Surgical Trial and the Dutch Gastric Cancer Trial (DGCT), were conducted in the 1990s to examine the benefit of extended lymphadenectomy in curative gastrectomy for patients with gastric cancer [1,2]. Initially, these RCTs reported that a D2 lymphadenectomy did not result in improved survival. Patient selection, surgeon inexperience, and lack of quality control measures have been proposed to explain the discrepancies between these findings and the experience in Asia, and in particular why these two RCTs reported increased morbidity and mortality with D2 lymphadenectomy $[13,21]$. In subgroup analysis, increased postoperative morbidity and mortality were felt to be attributable to the resection of the spleen and pancreas during extended lymphadenectomy $[2,24]$. In the DGCT, all patients randomized to D2 lymphadenectomy were required to have resection of the spleen and pancreas, though neither was resected in $62 \%$ of patients in the D2 arm of the trial [1]. In the MRC trial, resection of the spleen and pancreas with D2 lymphadenectomy was required in patients with cancers in the middle or upper third of the stomach, and neither was resected in $35 \%$ of patients in this arm of the trial [25]. Preservation of the spleen and pancreas during D2 lymphadenectomy has been advocated by the authors of the DGCT-recommendations that were made on the basis of post-hoc subgroup analysis and must be interpreted accordingly [24]. Despite assertions from both trials that resection of the spleen and pancreas in the D2 arm was responsible for increased operative morbidity and mortality, no RCT has shown a survival advantage when performing pancreas-preserving or spleen-preserving D2 resection compared to the traditional D2 resection [26-28]. In addition, the role of the spleen in cancer immunology has been cited as a reason to consider spleen preservation during extended lymphadenectomy [12].
Despite these concerns regarding splenectomy and pancreaticosplenectomy, these procedures continue to be performed alongside extended lymphadenectomy for gastric cancer $[29,30]$. The current Japanese Gastric Cancer Association guidelines recommend that D2 lymphadenectomy with splenectomy be considered for patients with T2-T4 tumors along the greater curvature of the upper stomach [31]. Conversely, other groups recommend selective performance of splenectomy or distal pancreatectomy [32]. These groups argue that preservation of the spleen and pancreas has no detrimental effect on survival. Given these conflicting views, we present a systematic review of the evidence for preservation of the spleen and pancreas in extended lymphadenectomy during surgical therapy for gastric cancer.

\section{Methods}

\section{Data sources}

Electronic literature searches were conducted in Medline and EMBASE from 1 January 1998 to 31 December 2009 according to the search algorithm presented in Appendix A in the Electronic supplementary material. Search terms included [exp Stomach Cancer/or ((gastric or stomach) adj1 cancer\$) or ((gastric or stomach) adj1 carcinoma) or ((gastric or stomach) adj1 adenocarcinoma) or ((gastric or stomach) adj1 neoplasm\$)).mp.] and [((negative or resection) adj2 margin\$).mp. or exp frozen section/or exp GASTRECTOMY/or ((gastric or stomach) adj2 resect\$).mp. $[\mathrm{mp}=$ title, abstract, subject headings, heading word, drug trade name, original title, device manufacturer, drug manufacturer name] or omentectom\$.mp. or multivisceral resection\$.mp.] and [(spleen or pancreas or splenectomy or pancreaticosplenetomy or spleno-pancreatectomy or pancreatectomy or spleen preservation or pancreas preservation).mp.] and [clinical trial/or controlled clinical trial/or exp comparative study/or meta-analysis/or multicenter study/or exp practice guideline/or randomized controlled trial/] not [case report/or review]. A separate search of the Cochrane Central Register of Controlled Trials (1998-2009) was performed using the search term gastric cancer. No attempt was made to locate unpublished material.

Study selection and review process

To be eligible, studies had to meet the following criteria: (1) investigation of splenectomy and/or pancreaticosplenectomy in newly (not recurrent) diagnosed patients with histopathology confirmed gastric adenocarcinoma; (2) patients underwent surgery, and complication or survival data were reported; (3) involved human subjects with a minimum of 30 patients; (4) published in peer-reviewed journals from 1998 
to 2009; (5) published in English. Studies were excluded according to the following exclusion criteria: (1) involved animals and/or ex vivo samples; (2) involved patients with mixed cancer or studies investigating splenectomy and/or pancreaticosplenectomy in other cancers with no separate analysis of gastric cancer subjects; (3) studies that did not provide sufficient information to determine complication or survival data; (4) review articles, meta-analyses, abstracts, conference proceedings, editorials/letters, and case reports. All electronic search titles, selected abstracts, and full-text article were independently reviewed by a minimum of two reviewers (NC, LH, RC, RS). Reference lists from review papers and relevant articles were also examined for additional studies that met our inclusion criteria. Disagreements on study inclusion/exclusion were resolved with a consensus meeting of the reviewers.

\section{Data extraction}

A systematic approach to data extraction was used to produce a descriptive summary of participants, interventions, and study findings. Data abstracted included the type of study, number of patients, age, gender, TMN stage, and details of the type of resection. Surgical outcomes, including the number of lymph nodes examined, presence or absence of residual tumor (R0 status), operative time, need for reoperation, length of hospital stay, postoperative complications, and operative or hospital mortality, were extracted. Survival data including length of follow-up, overall survival and survival by subgroups were extracted. The first reviewer (RS) independently extracted the data, and a second reviewer (SB) checked the data extraction. No attempt was made to contact authors for additional information. All RCTs were assessed for quality using the Jadad scoring system [33].

Data analysis

Randomized controlled trials were identified from the review. Statistical analysis and figure generation were performed using Review Manager 5.0 software (The Cochrane Collaboration, Copenhagen, Denmark). Using the Mantel-Haenszel method, odds ratios (OR) with $95 \%$ confidence intervals $(95 \% \mathrm{CI})$ were calculated for dichotomous variables. $P<0.05$ was defined as significant. No sensitivity analysis was performed.

\section{Results}

Literature search

A total of 3,608 titles/abstracts were identified from the electronic searches and reference lists for preliminary

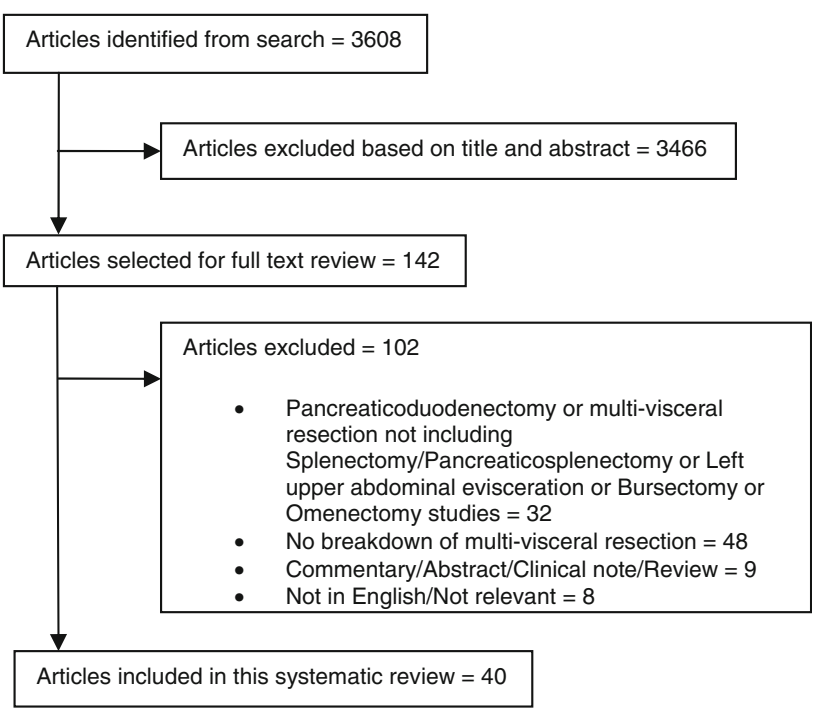

Fig. 1 Article selection flow

review. After removal of duplicates and screening for relevant titles and abstracts, a total of 142 articles were submitted for a full-text review. A total of 40 articles involving 6,354 patients met our inclusion criteria and were included in this review (Fig. 1). Of these, 3 studies were RCTs comparing standard D2 lymphadenectomy with spleenpreserving D2 lymphadenectomy [26, 28, 30] (Table 1), 1 was an RCT comparing standard D2 lymphadenectomy with pancreas-preserving D2 lymphadenectomy [27] (Table 1), 6 were prospective studies examining the extent of lymphadenectomy [1, 2, 9, 10, 34, 35] (Table 2), and 32 were retrospective studies [7, 8, 11, 12, 14-19, 21-23, 29, 36-51] (Table 3). The four RCTs examining spleen and/or pancreas preservation were evaluated and given Jadad scores between 1 and 3 (Table 1). The six prospective studies on the extent of lymphadenectomy were used to identify patients undergoing D2 or D3 lymphadenectomy with and without preservation of the spleen and/or pancreas (Table 2).

\section{Surgical outcomes}

Data for surgical outcomes were pooled from the 40 articles included in the review. No significant difference in overall complications, pancreatic fistula, anastomotic leak, or operative mortality was found in the individual RCT results (Table 1). A forest plot shows the meta-analysis of operative survival of the three RCTs comparing gastrectomy with spleen resection or preservation, and demonstrates no statistically significant difference (OR 1.59, 95\% CI 0.44-5.79) (Fig. 2). In the six prospective lymphadenectomy trials, preservation of the spleen and pancreas was associated with fewer overall complications in two studies and fewer operative deaths in one study; in the remaining 
Table 1 Summary of SP-PS prospective randomized trials and their outcomes

\begin{tabular}{|c|c|c|c|c|c|c|c|c|}
\hline Study & Patients $(N)$ & Jadad score & $\begin{array}{l}\text { Overall surgical } \\
\text { complication } \\
\text { rate (\% of pts) }\end{array}$ & $\begin{array}{l}\text { Leakage rate } \\
\text { (\% of pts) }\end{array}$ & $\begin{array}{l}\text { Peri-operative } \\
\text { mortality } \\
\text { (\% of pts) }\end{array}$ & $\begin{array}{l}\text { R0 } \\
\text { (\% of pts) }\end{array}$ & $\begin{array}{l}\text { Overall } \\
\text { survival } \\
(\%)\end{array}$ & Significance \\
\hline Csendes [26] & $\begin{array}{l}\mathrm{SP}=97 \\
\mathrm{SR}=90\end{array}$ & $2 / 5$ & NR & NR & $\begin{array}{l}3.10 \\
4.40\end{array}$ & NR & $\begin{array}{l}5 \text { years: } 36 \\
5 \text { years: } 42\end{array}$ & All NS \\
\hline Furukawa [27] & $\begin{array}{l}\mathrm{PR}=55 \\
\mathrm{PP}=55\end{array}$ & $1 / 5$ & NR & $\begin{array}{l}\text { PF: } 14.5 \\
\text { AL: } 3.6 \\
\text { PF: } 9.1 \\
\text { AL: } 3.6\end{array}$ & NR & NR & $\begin{array}{l}5 \text { years: } 80 \\
10 \text { years: } 64.4 \\
5 \text { years: } 76.7 \\
10 \text { years: } 73.3\end{array}$ & All NS \\
\hline Okinaga [30] & $\begin{array}{l}\mathrm{SR}=12 \\
\mathrm{SR}+\mathrm{IT}=11 \\
\mathrm{SP}=12 \\
\mathrm{SP}+\mathrm{IT}=10\end{array}$ & $3 / 5$ & NR & NR & NR & 100 & $\begin{array}{l}5 \text { years: } 71.4 \\
5 \text { years: } 80 \\
5 \text { years: } 87.5 \\
5 \text { years: } 100\end{array}$ & All NS \\
\hline $\mathrm{Yu}$ [28] & $\begin{array}{l}S P=103 \\
S R=104\end{array}$ & $3 / 5$ & $\begin{array}{l}8.70 \\
15.40\end{array}$ & $\begin{array}{l}\text { EF: } 0 \\
\text { EF: } 1.9\end{array}$ & $\begin{array}{l}1.00 \\
1.90\end{array}$ & $\begin{array}{l}78.6 \\
84.6\end{array}$ & $\begin{array}{l}5 \text { years: } 48.8 \\
5 \text { years: } 54.8\end{array}$ & All NS \\
\hline
\end{tabular}

Significance corresponds to the noted superscripts

$A L$ anastomotic leakage, $E F$ enterocutaneous fistula, $I T$ immunotherapy, $N R$ not reported, $N S$ not significant, $P F$ pancreatic fistula, $P P$ pancreaspreserving, $P R$ pancreaticosplenectomy, pts patients, $R O$ resection with no residual tumor, $S P$ spleen-preserving, $S R$ splenectomy

studies, the differences were non-significant or not reported (Table 2). In the retrospective studies, preservation of the spleen was associated with fewer complications in three studies, preservation of the pancreas was associated with fewer overall complications in five studies, and decreased operative mortality in one study. In the remaining 33 retrospective studies, there were no significant differences in complications and operative mortality in 10 spleen-preserving trials and 13 pancreas-preservation studies, respectively; however, 13 studies did not report on this.

\section{Overall survival}

Overall survival was reported in 29 studies. In the RCTs, there was no statistically significant difference between overall survival in patients who underwent extended lymphadenectomy with or without spleen preservation $[26,28$, 30] (Table 1). A forest plot illustrates the meta-analysis of overall survival of the three RCTs comparing gastrectomy with spleen resection or preservation, and demonstrates no statistically significant difference (OR 0.97, 95\% CI 0.56-1.68) (Fig. 3). Spleen preservation was associated with improved overall survival in two prospective lymphadenectomy trials, and there was no difference in another prospective lymphadenectomy trial (Table 2). In the retrospective studies, spleen preservation was associated with improved survival in 8 studies, diminished survival in 1 study, and no statistically significant difference in survival in 12 studies (Tables 3, 4, 5). In the one RCT comparing patients who underwent extended lymphadenectomy with or without pancreas preservation, there was no statistically significant difference in overall survival [27] (Table 1).
In the prospective lymphadenectomy trials, pancreaticosplenectomy was associated with decreased survival in one study and with no difference in overall survival in two studies (Table 2). Three prospective lymphadenectomy trials did not report survival. Two retrospective studies found pancreaticosplenectomy was associated with a statistically significant decrease in overall survival (Table 6). Six retrospective studies reported no statistically significant difference in survival in patients who underwent D2 resection with or without pancreas resection, and an additional six studies did not report overall survival (Table 7).

Retrospective studies that report survival data with subgroup analysis are listed in Appendix B in the Electronic supplementary material. Positive lymph nodes in the splenic artery and hilum were associated with decreased survival [15, 19, 22, 44, 48]. Extended lymphadenectomy with spleen resection for patients was associated with decreased survival in one study compared to spleen preservation when these nodes were positive [44]. R0 resection was associated with improved survival in patients in two studies $[14,42]$.

\section{Discussion}

For patients with gastric cancer, curative therapy rests on adequate surgical resection and lymphadenectomy. Extended lymphadenectomy is thought to improve outcomes in patients with advanced gastric cancer. However, the removal of the spleen and pancreas to facilitate lymph node harvest along the splenic artery and hilum, and not for direct invasion, has been called into question. Instead, 
Table 2 Summary of prospective trials and their outcomes

\begin{tabular}{|c|c|c|c|c|c|c|c|}
\hline Study & Patients $(N)$ & $\begin{array}{l}\text { Overall surgical } \\
\text { complication rate } \\
\text { (\% of pts) }\end{array}$ & $\begin{array}{l}\text { Leakage rate } \\
(\% \text { of pts) }\end{array}$ & $\begin{array}{l}\text { Peri-operative } \\
\text { mortality } \\
\text { (\% of pts) }\end{array}$ & $\begin{array}{l}\mathrm{R} 0 \\
\text { (\% of pts) }\end{array}$ & $\begin{array}{l}\text { Overall } \\
\text { survival (\%) }\end{array}$ & Significance \\
\hline \multirow[t]{4}{*}{ Bonenkamp [1] } & $\mathrm{SR}=124$ & 55 & \multirow[t]{4}{*}{ NR } & 15 & \multirow[t]{4}{*}{100} & \multirow[t]{4}{*}{ NR } & \multirow[t]{4}{*}{ NR } \\
\hline & $\mathrm{SP}=204$ & 36 & & 6 & & & \\
\hline & $\mathrm{PR}=98$ & 53 & & 11 & & & \\
\hline & $P P=230$ & 39 & & 9 & & & \\
\hline \multirow[t]{4}{*}{ Cuschieri [2] } & $\mathrm{SR}=131$ & $59^{\mathrm{a}}$ & \multirow[t]{4}{*}{ NR } & $17^{\mathrm{c}}$ & \multirow[t]{4}{*}{ NR } & 5 years: 33 & $P<0.001^{*, \mathrm{a}, \mathrm{b}, \mathrm{c}}$ \\
\hline & $\mathrm{SP}=69$ & $22^{\mathrm{a}}$ & & $6^{\mathrm{c}}$ & & 5 years: 46 & $P=0.01^{*, \mathrm{~d}}$ \\
\hline & $\mathrm{PR}=113$ & $58^{\mathrm{b}}$ & & $16^{\mathrm{d}}$ & & 5 years: $25^{\mathrm{e}}$ & $P<0.05^{*, \mathrm{e}}$ \\
\hline & $\mathrm{PP}=87$ & $30^{\mathrm{b}}$ & & $9^{\mathrm{d}}$ & & 5 years: $46^{\mathrm{e}}$ & \\
\hline \multirow[t]{4}{*}{ Edwards [34] } & $\mathrm{SR}=7$ & NR & \multirow[t]{4}{*}{ NR } & \multirow[t]{4}{*}{ NR } & \multirow[t]{4}{*}{ NR } & 5 years: $43^{a}$ & \multirow[t]{4}{*}{$P<0.05^{\mathrm{a}}$} \\
\hline & $\mathrm{SP}=75$ & & & & & 5 years: $60^{\mathrm{a}}$ & \\
\hline & $\mathrm{PR}=3$ & & & & & 5 years: 66 & \\
\hline & $\mathrm{PP}=79$ & & & & & 5 years: 58 & \\
\hline \multirow[t]{4}{*}{ Kodera [9] } & $\mathrm{SR}=191$ & $33.5^{\mathrm{a}}$ & \multirow[t]{4}{*}{ NR } & \multirow[t]{4}{*}{ NR } & \multirow[t]{4}{*}{ NR } & \multirow[t]{4}{*}{$\mathrm{NR}$} & \multirow[t]{4}{*}{$P<0.001^{\mathrm{a}, \mathrm{b}}$} \\
\hline & $\mathrm{SP}=332$ & $19.3^{\mathrm{a}}$ & & & & & \\
\hline & $P R=22$ & $59.1^{\mathrm{b}}$ & & & & & \\
\hline & $\mathrm{PP}=501$ & $23^{\mathrm{b}}$ & & & & & \\
\hline \multirow[t]{4}{*}{$\mathrm{Wu}[35]$} & $\mathrm{SR}=18$ & 33.3 & \multirow[t]{4}{*}{ NR } & \multirow[t]{4}{*}{ NR } & \multirow[t]{4}{*}{ NR } & \multirow[t]{4}{*}{ NR } & RR-SR: 5.84 (1.94-17.6) \\
\hline & $\mathrm{SP}=203$ & 7.9 & & & & & RR-PR: 6.21 (1.87-20.6) \\
\hline & $P R=14$ & 35.7 & & & & & \\
\hline & $\mathrm{PP}=207$ & 8.2 & & & & & \\
\hline \multirow[t]{6}{*}{ Yonemura [10] } & $\mathrm{SR}=124$ & NR & PF: 17.6 & \multirow[t]{5}{*}{ NR } & \multirow[t]{5}{*}{ NR } & 5 years: 48.6 & \multirow[t]{6}{*}{ All NS } \\
\hline & & & AL: 8.8 & & & & \\
\hline & $\mathrm{SP}=145$ & & NR & & & 5 years: 58.1 & \\
\hline & $\mathrm{PR}=55$ & & PF: 14.6 & & & 5 years: 53.8 & \\
\hline & & & AL: 8.3 & & & & \\
\hline & $\mathrm{PP}=214$ & & NR & & & 5 years: 53.8 & \\
\hline
\end{tabular}

Significance corresponds to the noted superscripts

$A L$ anastomotic leakage, $N R$ not reported, $N S$ not significant, $P F$ pancreatic fistula, $P P$ pancreas-preserving, $P R$ pancreaticosplenectomy, $p t s$ patients, $R O$ resection with no residual tumor, $R R$ relative risk, $S P$ spleen-preserving, $S R$ splenectomy

* Significance when comparing removal of organs in both D1 + D2 versus no removal in D1 + D2

preservation of the spleen and pancreas during D2 lymphadenectomy has been proposed by some as a safer procedure with improved short-term outcomes and no detriment to long-term survival. In this review, we systematically reviewed 40 articles, both prospective and retrospective, to determine and summarize the evidence for preservation of the spleen and pancreas during extended lymphadenectomy. D2 lymphadenectomy with preservation of the spleen and pancreas is likely associated with a decreased rate of complications and operative mortality. There is no clear association of long-term survival with spleen and pancreas preservation in D2 lymph node dissection.

The results of two large RCTs from Europe examining extended lymphadenectomy argued that the increased morbidity and mortality observed in these trials was attributable to splenectomy and distal pancreatectomy $[1,2]$. Since these conclusions were based on post-hoc subgroup analysis, they must be carefully interpreted. The morbidity and mortality of D2 resections in these trials were much higher than in Asian centers, and thus, some have argued that the European trials may have been biased against long-term benefit by short-term mortality from complications of splenectomy and distal pancreatectomy. Subsequently, a multicenter RCT performed by the Italian Gastric Cancer Study Group (IGCSG) reported improved operative morbidity and mortality, with no difference in short-term outcomes for D1 and D2 lymphadenectomy [32]. In the IGCSG trial, splenectomy was performed only for cancers in the upper left of the stomach or near the greater curvature, and pancreatectomy was not routine [32]. Improvements in short-term outcomes have been 
Table 3 Retrospective studies supporting spleen-preserving lymphadenectomy

\begin{tabular}{|c|c|c|c|c|c|c|c|}
\hline Study & Patients $(N)$ & $\begin{array}{l}\text { Overall surgical } \\
\text { complication rate } \\
(\% \text { of pts })\end{array}$ & $\begin{array}{l}\text { Leakage rate } \\
\text { (\% of pts) }\end{array}$ & $\begin{array}{l}\text { Peri-operative } \\
\text { mortality } \\
(\% \text { of pts) }\end{array}$ & $\begin{array}{l}\text { R0 } \\
\text { (\% of pts) }\end{array}$ & $\begin{array}{l}\text { Overall } \\
\text { survival (\%) }\end{array}$ & Significance \\
\hline \multirow[t]{2}{*}{ Fatouros [29] } & $S R=67$ & 19.40 & AL: 12 & 0 & R0: 100 & $\begin{array}{l}5 \text { years: } 40^{\mathrm{a}} \\
10 \text { years: } 30^{\mathrm{b}}\end{array}$ & $P=0.004^{\mathrm{a}, \mathrm{b}}$ \\
\hline & $\mathrm{SP}=59$ & 18.60 & AL: 10 & 3.40 & R0: 100 & $\begin{array}{l}5 \text { years: } 63^{\mathrm{a}} \\
10 \text { years: } 57^{\mathrm{b}}\end{array}$ & \\
\hline \multirow[t]{3}{*}{ Kasakura [14] } & $\mathrm{SR}=78$ & $39.7^{\mathrm{a}}$ & $\begin{array}{l}\text { PF: } 5.1^{\mathrm{b}} \\
\text { AL: } 9.0^{\mathrm{c}}\end{array}$ & $0^{\mathrm{d}}$ & R0: 76.9 & NR & $P<0.0001^{\mathrm{a}, \mathrm{b}, \mathrm{c}}$ \\
\hline & $P R=105$ & $75.2^{\mathrm{a}}$ & $\begin{array}{l}\text { PF: } 31.4^{\mathrm{b}} \\
\text { AL: } 15.2^{\mathrm{c}}\end{array}$ & $0.95^{\mathrm{d}}$ & R0: 68.6 & & $P=0.02^{\mathrm{d}}$ \\
\hline & $\mathrm{SP}=1755$ & 17.80 & $\begin{array}{l}\text { PF: } 0.5^{\mathrm{b}} \\
\text { AL: } 5.0^{\mathrm{c}}\end{array}$ & $0.06^{\mathrm{d}}$ & R0: 83.6 & & \\
\hline Lee [39] & $\begin{array}{l}\mathrm{SR}=492 \\
\mathrm{SP}=173\end{array}$ & NR & NR & $\begin{array}{l}0.61 \\
0\end{array}$ & $\begin{array}{l}\text { R0: } 100 \\
\text { R0: } 100\end{array}$ & $\begin{array}{l}5 \text { years: } 52.9^{\mathrm{a}} \\
5 \text { years: } 64.8^{\mathrm{a}}\end{array}$ & $P<0.001^{\mathrm{a}}$ \\
\hline Nanthakumaran [43] & $\begin{array}{l}\mathrm{SR}=131 \\
\mathrm{PR}=30 \\
\mathrm{SP}=309\end{array}$ & NR & NR & NR & NR & $\begin{array}{l}1 \text { year: } 50.9^{\mathrm{a}} \\
1 \text { year: } 39.1^{\mathrm{a}} \\
1 \text { year: } 60^{\mathrm{a}}\end{array}$ & $P<0.05^{\mathrm{a}}$ \\
\hline Oh [44] & $\begin{array}{l}S R=99 \\
S P=267\end{array}$ & $\begin{array}{l}29.3^{\mathrm{a}} \\
11.6^{\mathrm{a}}\end{array}$ & $\begin{array}{l}\text { AL: } 0 \\
\text { AL: } 0.75\end{array}$ & $\begin{array}{l}1.00 \\
0.70\end{array}$ & NR & $\begin{array}{l}\text { MNS: } 56.7 \text { months }{ }^{\mathrm{b}} \\
\text { MNS: } 72.0 \text { months }^{\mathrm{b}}\end{array}$ & $P<0.001^{\mathrm{a}, \mathrm{b}}$ \\
\hline Shen [47] & $\begin{array}{l}\mathrm{SR}=347 \\
\mathrm{SP}=102\end{array}$ & NR & NR & NR & NR & MS: 69.6 months & $P=0.027^{\mathrm{a}}$ \\
\hline Toneri [49] & $\mathrm{SP}=62$ & NR & NR & NR & NR & $\begin{array}{l}1 \text { year: } 33.3^{\mathrm{a}} \\
3 \text { years: } 0^{\mathrm{b}} \\
5 \text { years: } 0^{\mathrm{c}} \\
1 \text { year: } 83.7^{\mathrm{a}} \\
3 \text { years: } 70.3^{\mathrm{b}} \\
5 \text { years: } 57.7^{\mathrm{c}}\end{array}$ & $P=0.0001^{\mathrm{a}, \mathrm{b}, \mathrm{c}}$ \\
\hline Verlato [50] & $\begin{array}{l}\mathrm{SR}=98 \\
\mathrm{PR}=43 \\
\mathrm{SP}=891\end{array}$ & $\begin{array}{l}29.6^{\mathrm{a}} \\
39.5^{\mathrm{a}} \\
17.4^{\mathrm{a}}\end{array}$ & NR & 3.70 & NR & $\begin{array}{l}5 \text { years: } 36.1^{\mathrm{b}} \\
5 \text { years: } 16.7^{\mathrm{b}} \\
5 \text { years: } 55.5^{\mathrm{b}}\end{array}$ & $P<0.001^{\mathrm{a}, \mathrm{b}}$ \\
\hline \multirow[t]{2}{*}{ Zhang [51] } & $\mathrm{SR}=38$ & 18.40 & $\begin{array}{l}\text { AL: } 0 \\
\text { PF: } 0\end{array}$ & 0 & NR & $\begin{array}{l}5 \text { years: } 16.9^{\mathrm{a}} \\
\text { MNS: } 21.8 \text { months } \\
\text { MS: } 18.9 \text { months }\end{array}$ & $P=0.008^{\mathrm{a}}$ \\
\hline & $\mathrm{SP}=70$ & 14.00 & $\begin{array}{l}\text { AL: } 0 \\
\text { PF: } 0\end{array}$ & 1.4 & & $\begin{array}{l}5 \text { years: } 38.7^{\mathrm{a}} \\
\text { MNS: } 28.6 \text { months } \\
\text { MS: } 21.9 \text { months }\end{array}$ & \\
\hline
\end{tabular}

Significance corresponds to the noted superscripts

$A L$ anastomotic leakage, $N$ number, $M N S$ mean survival, $M S$ median survival, $N R$ not reported, $P F$ pancreatic fistula, $P R$ pancreaticosplenectomy, pts patients, $R O$ resection with no residual tumor, $S P$ spleen-preserving, $S R$ splenectomy

attributed to advances in patient selection, perioperative care, surgeon training, surgeon and hospital volume, and quality control [32].

Csendes et al. [26] conducted an RCT comparing extended lymphadenectomy with and without splenectomy, and found that despite some increase in postoperative complications, there was no difference in operative mortality or overall 5-year survival. Similar results were found in the RCT by Yu et al. [28], with no statistically significant difference in operative mortality or overall 5-year survival, despite an increase in some complications. Both RCTs showed a trend towards increased overall 5-year survival with resection of the spleen. The study by Okinaga et al. [30] was comparatively much smaller, and again, no significant difference in overall survival with spleen preservation was demonstrated. Furukawa et al. [27] also found no statistically significant increase in the reported fistula or leaks rate, and no difference in overall survival in patients 


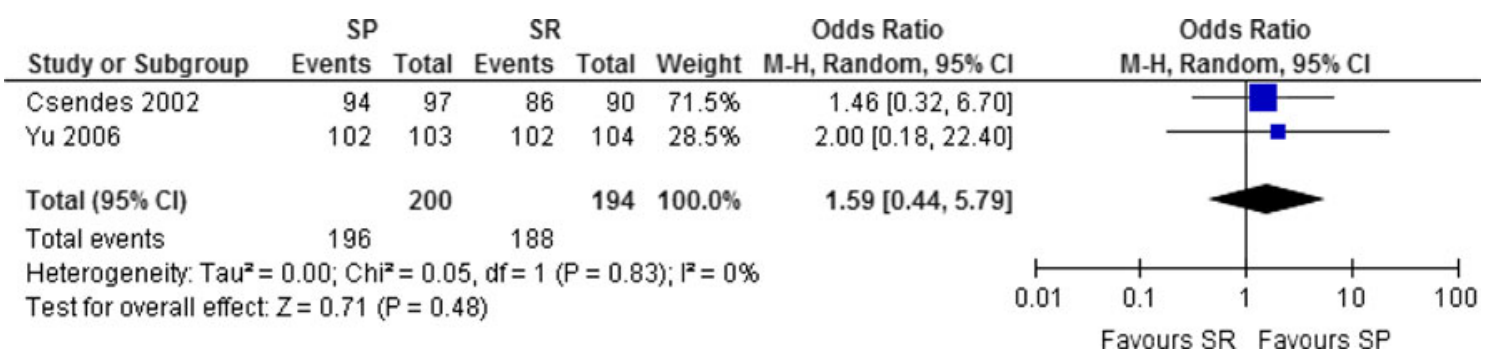

Fig. 2 Meta-analysis of operative mortality for patients undergoing D2 lymphadenectomy in randomized trials of spleen-preservation versus spleen-resection

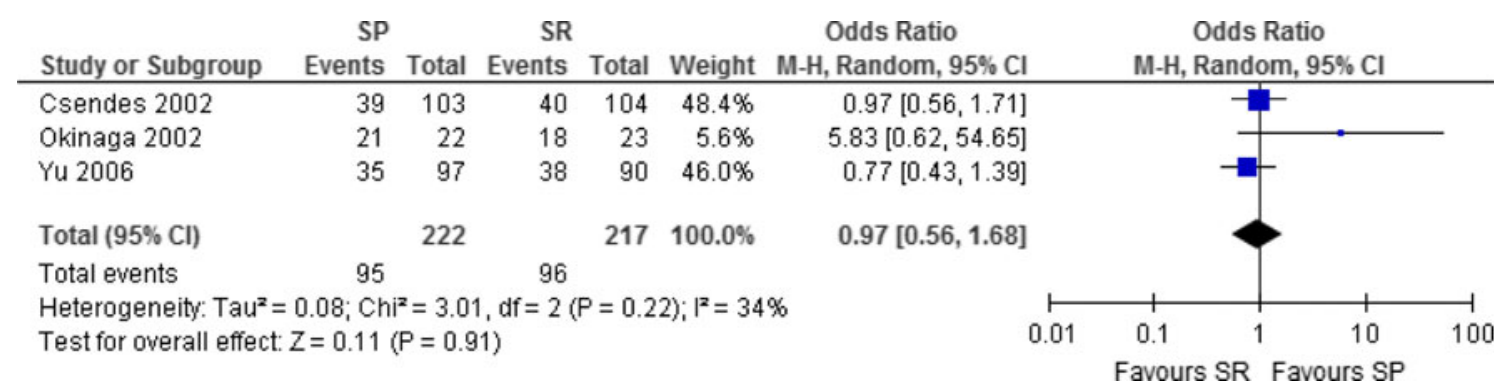

Fig. 3 Meta-analysis of 5-year survival for patients undergoing D2 lymphadenectomy in randomized trials of spleen-preservation versus spleenresection

Table 4 Retrospective studies supporting spleen resection with lymphadenectomy

\begin{tabular}{lllllll}
\hline Study & Patients $(N)$ & $\begin{array}{l}\text { Overall surgical } \\
\text { complication rate } \\
(\% \text { of pts })\end{array}$ & $\begin{array}{l}\text { Leakage rate } \\
(\% \text { of pts })\end{array}$ & $\begin{array}{l}\text { Peri-operative } \\
\text { mortality } \\
(\% \text { of pts })\end{array}$ & $\begin{array}{l}\text { R0 } \\
(\% \text { of pts })\end{array}$ & $\begin{array}{l}\text { Overall } \\
\text { survival }(\%)\end{array}$ \\
\hline Huang [7] & SR $=73$ & 17.8 & $\begin{array}{l}\text { AL: } 2.7 \\
\text { PF: } 5.5\end{array}$ & 4.1 & NR & 5 years: $30^{\mathrm{a}}$ \\
& & AL: 0.7 & 3.5 & 5 years: $19.7^{\mathrm{a}}$ \\
\end{tabular}

Significance corresponds to the noted superscripts

$A L$ anastomotic leakage, $N$ number, $N R$ not reported, $P F$ pancreatic fistula, $p t s$ patients, $R O$ resection with no residual tumor, $S P$ spleenpreserving, $S R$ splenectomy

who underwent pancreas-preserving D2 lymphadenectomy compared to traditional D2 lymphadenectomy. One potential explanation for these findings is that these trials were inadequately powered to detect a difference. Three of the four trials did not provide power calculations [26, 27, 30]. Power calculations were performed by $\mathrm{Yu}$ et al. [28]; however, patient numbers were adequate to only detect a $20 \%$ difference in survival with a power of $80 \%$. Another explanation is that there may yet be a more specific subgroup that does have improved outcomes with resection of the spleen and/or pancreas, but this was undetectable in the midst of other improperly selected patients. The Japan Clinical Oncology Group multicenter RCT, comparing gastrectomy with or without spleen preservation, has completed accrual, and final results are expected when the 5-year survival data are available [13, 52]. This trial was designed as a non-inferiority study powered to detect differences in overall survival and will have 250 patients in each arm [52]. Ideally, this large trial will be able to identify which subgroups, if any, may benefit from splenectomy along with extended lymphadenectomy.

The possibility that there may be as yet unidentified subgroups that would benefit or alternatively be harmed by splenic and/or pancreatic resection with gastric surgery may also lie in the debated role of the spleen in gastric cancer. The function of the spleen with respect to cancer immunotherapy in patients with gastric cancer was discussed by some of the studies in the review, as the spleen accounts for $25 \%$ of the total body lymphoid tissue [12] The splenic functions include removal of neoplastic cells from the blood stream, as well as contributing to lymphocyte function. The role of the spleen has been described 
Table 5 Retrospective studies with no difference in survival with spleen-preserving lymphadenectomy

\begin{tabular}{|c|c|c|c|c|c|c|c|}
\hline Study & Patients $(N)$ & $\begin{array}{l}\text { Overall surgical } \\
\text { complication rate } \\
\text { (\% of pts) }\end{array}$ & $\begin{array}{l}\text { Leakage } \\
\text { rate (\% of pts) }\end{array}$ & $\begin{array}{l}\text { Peri-operative } \\
\text { mortality } \\
\text { (\% of pts) }\end{array}$ & $\begin{array}{l}\text { R0 } \\
\text { (\% of pts) }\end{array}$ & $\begin{array}{l}\text { Overall } \\
\text { survival (\%) }\end{array}$ & Significance \\
\hline \multirow[t]{6}{*}{ Erturk [12] } & $\mathrm{SR}=38$ & 9.8 & AL: 5.3 & NR & 100 & 5 years: 44.7 & All NS \\
\hline & & & PF: 2.6 & & & MNS: 62.6 months & \\
\hline & & & & & & MS: 55 months & \\
\hline & $\mathrm{SP}=23$ & 3.3 & AL: 4.3 & & 100 & 5 years: 47.8 & \\
\hline & & & & & & MNS: 64.6 months & \\
\hline & & & & & & MS: 60 months & \\
\hline \multirow[t]{2}{*}{ Li [40] } & $\mathrm{SR}=62$ & 27.4 & NR & NR & NR & 5 years: 55 & All NS \\
\hline & $\mathrm{SP}=69$ & 21.7 & & & & 5 years: 66 & \\
\hline \multirow[t]{2}{*}{ Saji [46] } & $\mathrm{SR}=78$ & 34.6 & NR & 0 & NR & 5 years: 54 & All NS \\
\hline & $\mathrm{SP}=175$ & 33.7 & & 0 & & 5 years: 72 & \\
\hline \multirow[t]{4}{*}{ Sasada [22] } & $\mathrm{SR}=201$ & 27.4 & AL: 6.0 & 0.50 & NR & NR & $P<0.001^{\mathrm{a}}$ \\
\hline & & & PF: $8.5^{\mathrm{a}}$ & & & & \\
\hline & $\mathrm{SP}=148$ & 21.6 & AL: 3.4 & 0 & & & \\
\hline & & & PF: $0^{\mathrm{a}}$ & & & & \\
\hline \multirow[t]{2}{*}{ Schmid [16] } & $\mathrm{SR}=94$ & 48.9 & AL: 10.6 & 1 & 71.3 & 5 years: 56 & All NS \\
\hline & $\mathrm{SP}=84$ & 35.7 & AL: 3.6 & 2.4 & 77.4 & 5 years: 60.3 & \\
\hline Shin [48] & $\mathrm{SR}=319$ & NR & NR & NR & 100 & $\mathrm{NR}^{*}$ & $\mathrm{NR}^{*}$ \\
\hline
\end{tabular}

Significance corresponds to the noted superscripts

$A L$ anastomotic leakage, $M N S$ mean survival, $M S$ median survival, $N R$ not reported, $N S$ not significant, $P F$ pancreatic fistula, $p t s$ patients, $R O$ resection with no residual tumor, $S P$ spleen-preserving, $S R$ splenectomy

* Survival calculated only in subgroups, see Appendix B in Electronic supplementary material

Table 6 Retrospective studies supporting a survival benefit with pancreas-preserving lymphadenectomy

\begin{tabular}{|c|c|c|c|c|c|c|c|}
\hline Study & Patients $(N)$ & $\begin{array}{l}\text { Overall surgical } \\
\text { complication rate } \\
(\% \text { of pts })\end{array}$ & $\begin{array}{l}\text { Leakage rate } \\
\text { (\% of pts) }\end{array}$ & $\begin{array}{l}\text { Peri-operative } \\
\text { mortality } \\
(\% \text { of pts })\end{array}$ & $\begin{array}{l}\text { R0 } \\
\text { (\% of pts) }\end{array}$ & $\begin{array}{l}\text { Overall } \\
\text { survival (\%) }\end{array}$ & Significance \\
\hline \multirow[t]{6}{*}{ Qin [37] } & \multirow[t]{2}{*}{$\mathrm{SR}=216$} & \multirow[t]{2}{*}{4.20} & \multirow[t]{6}{*}{ NR } & \multirow[t]{2}{*}{0.90} & \multirow[t]{2}{*}{93.1} & 5 years: $57.4^{\mathrm{a}}$ & $P<0.01^{\mathrm{a}}$ \\
\hline & & & & & & 10 years: $47.4^{\mathrm{b}}$ & $P<0.05^{\mathrm{b}}$ \\
\hline & \multirow[t]{2}{*}{$\mathrm{PR}=30$} & \multirow[t]{2}{*}{40} & & \multirow[t]{2}{*}{3.30} & \multirow[t]{2}{*}{93.3} & 5 years: $37^{\mathrm{a}}$ & \\
\hline & & & & & & 10 years: $30^{\mathrm{b}}$ & \\
\hline & \multirow[t]{2}{*}{$\mathrm{SP}=63$} & \multirow[t]{2}{*}{0} & & \multirow[t]{2}{*}{0} & \multirow[t]{2}{*}{93.7} & 5 years: $57.5^{\mathrm{a}}$ & \\
\hline & & & & & & 10 years: $52^{\mathrm{b}}$ & \\
\hline \multirow[t]{4}{*}{ Takeuchi [17] } & \multirow[t]{2}{*}{$\mathrm{PR}=65$} & \multirow[t]{4}{*}{ NR } & PF: $20^{\mathrm{a}}$ & 3.10 & \multirow[t]{4}{*}{ NR } & 5 years: $32^{\mathrm{b}}$ & $P=0.001^{\mathrm{a}}$ \\
\hline & & & AL: 9.2 & & & & \\
\hline & \multirow[t]{2}{*}{$\mathrm{PP}=98$} & & PF: $4.1^{\mathrm{a}}$ & \multirow[t]{2}{*}{5.10} & & 5 years: $64.9^{\mathrm{b}}$ & $P<0.001^{\mathrm{b}}$ \\
\hline & & & AL: 6.1 & & & & \\
\hline
\end{tabular}

Significance corresponds to the noted superscripts

$A L$ anastomotic leakage, $N$ number, $N R$ not reported, $N S$ not significant, $P D$ pancreaticoduodenectomy, $P F$ pancreatic fistula, $P P$ pancreaspreserving, $P R$ pancreaticosplenectomy, $p t s$ patients, $R O$ resection with no residual tumor, $S P$ spleen-preserving, $S R$ splenectomy

as both enhancing and suppressing the anti-tumor immune response [12, 46]. Okinaga et al. [30] postulated that splenic lymphocytes have a higher cytotoxic activity in early stage cancer, while increased suppressor activity in later stage cancer. They found that advanced stage gastric cancer patients who underwent gastrectomy with splenectomy who were treated with immunotherapy had improved overall survival [30].

Performing splenectomy and distal pancreatectomy during extended lymphadenectomy was thought to have facilitated removal of lymph nodes along the splenic artery and hilum $[8,14,18]$. However, indications for splenectomy and 
Table 7 Retrospective studies with no difference in survival with pancreas-preserving lymphadenectomy

\begin{tabular}{|c|c|c|c|c|c|c|c|}
\hline Study & Patients $(N)$ & $\begin{array}{l}\text { Overall surgical } \\
\text { complication rate } \\
(\% \text { of pts })\end{array}$ & $\begin{array}{l}\text { Leakage rate } \\
\text { (\% of pts) }\end{array}$ & $\begin{array}{l}\text { Peri-operative } \\
\text { mortality } \\
(\% \text { of pts) }\end{array}$ & $\begin{array}{l}\text { R0 } \\
\text { (\% of pts) }\end{array}$ & $\begin{array}{l}\text { Overall } \\
\text { survival (\%) }\end{array}$ & Significance \\
\hline Chikara [8] & $\mathrm{PR}=111$ & NR & $\begin{array}{l}\text { PF: } 38.7 \\
\text { AL: } 5.4\end{array}$ & 0 & NR & NR & NR \\
\hline Gorbunov [36] & $\begin{array}{l}\mathrm{SR}=40 \\
\mathrm{SP}=243 \\
\mathrm{PR}=9 \\
\mathrm{PP}=274\end{array}$ & NR & NR & NR & NR & $\begin{array}{l}5 \text { years: } 12.5 \\
5 \text { years: } 19.3 \\
5 \text { years: } 0 \\
5 \text { years: } 19\end{array}$ & All NS \\
\hline Kikuchi [38] & $P R=104$ & NR & NR & NR & NR & NR* & NR* \\
\hline \multirow[t]{2}{*}{ Kitamura [21] } & $P R=190$ & NR & $\begin{array}{l}\text { PF: } 12.1 \\
\text { AL: } 12.1\end{array}$ & 4.7 & 65.3 & NR & All NS \\
\hline & $\mathrm{SR}=206$ & & $\begin{array}{l}\text { PF: } 0.5 \\
\text { AL: } 9.7\end{array}$ & 5.8 & 74.8 & & \\
\hline \multirow[t]{2}{*}{ Lo [41] } & $\mathrm{PR}=127$ & $42.5^{\mathrm{a}}$ & $\begin{array}{l}\text { AL: } 10.2 \\
\text { PF: } 3.9 \\
\text { CL: } 2.4\end{array}$ & 6.3 & NR & 5 years: 47.1 & $P=0.06^{\mathrm{a}}$ \\
\hline & $\mathrm{SP}=201$ & $32.3^{\mathrm{a}}$ & $\begin{array}{l}\text { AL: } 4.5 \\
\text { PF: } 1.5 \\
\text { CL: } 2.0\end{array}$ & 4.8 & & 5 years: 52.5 & \\
\hline Maehara [42] & $\begin{array}{l}\mathrm{PR}=39 \\
\mathrm{PP}=49\end{array}$ & NR & NR & NR & $\begin{array}{l}30.8 \\
\mathrm{NR}\end{array}$ & $\begin{array}{l}5 \text { years: } 3 \\
5 \text { years: } 10\end{array}$ & $P<0.05^{\mathrm{a}}$ \\
\hline Noguchi [15] & $\mathrm{PR}=272$ & NR & NR & NR & NR & NR* & NR* \\
\hline Ohno [19] & $\mathrm{PR}=169$ & NR & NR & NR & NR & NR & $\mathrm{NR}^{*}$ \\
\hline \multirow[t]{3}{*}{ Otsuji [11] } & $\mathrm{SR}=57$ & 40.40 & $\begin{array}{l}\text { AL: } 14.1 \\
\text { PF: } 1.8^{\mathrm{a}}\end{array}$ & NR & 91.2 & 5 years: 55.9 & $P=0.027^{\mathrm{a}}$ \\
\hline & $P R=46$ & 45.70 & $\begin{array}{l}\text { AL: } 15.2 \\
\text { PF: } 15.2^{\mathrm{a}}\end{array}$ & & 97.8 & 5 years: 40.7 & \\
\hline & $\mathrm{SP}=25$ & 36 & $\begin{array}{l}\text { AL: } 12 \\
\text { PF: } 4.0^{\mathrm{a}}\end{array}$ & & 88 & 5 years: 54.2 & \\
\hline Piso [45] & $P R=33$ & 36.40 & AL: 6.1 & 9.10 & 72.7 & $\begin{array}{l}\text { MS: } 13 \text { months } \\
5 \text { years: } 19\end{array}$ & All NS \\
\hline \multirow[t]{2}{*}{ Wang [23] } & $\mathrm{PS}=46$ & $52.2^{\mathrm{a}}$ & $\begin{array}{l}\text { AL: } 8.7 \\
\text { PF: } 10.9^{b}\end{array}$ & 4.30 & 95.7 & 5 years: 35.6 & $\begin{array}{l}P=0.008^{\mathrm{a}} \\
P=0.036^{\mathrm{b}}\end{array}$ \\
\hline & No PS $=38$ & $23.7^{\mathrm{a}}$ & $\begin{array}{l}\text { AL: } 5.3 \\
\text { PF: } 0^{\text {b }}\end{array}$ & 2.60 & 94.7 & 5 years: 42.4 & \\
\hline \multirow[t]{3}{*}{ Yamamoto [18] } & $\mathrm{SP}=145$ & $24.1^{\mathrm{a}, \mathrm{b}}$ & $\begin{array}{l}\text { AL: } 4.8 \\
\text { PF: } 2.8\end{array}$ & 1.40 & NR & NR & $P<0.006^{\mathrm{a}}$ \\
\hline & $\mathrm{PS}=74$ & $41.9^{\mathrm{b}}$ & $\begin{array}{l}\text { AL: } 2.7 \\
\text { PF: } 6.8\end{array}$ & 1.30 & & & $P<0.007^{\mathrm{b}}$ \\
\hline & $\mathrm{CG}=22$ & $9.1^{\mathrm{a}}$ & $\begin{array}{l}\text { AL: } 0 \\
\text { PF: } 0\end{array}$ & 0 & & & \\
\hline
\end{tabular}

Significance corresponds to the noted superscripts

$A L$ anastomotic leakage, $C G$ conventional gastrectomy, $C L$ chylous leak, met presence of metastasis, $M S$ median survival, $N$ number, $N R$ not reported, $N S$ not significant, $P F$ pancreatic fistula, $P P$ pancreas-preserving, $P R$ pancreaticosplenectomy, $p t s$ patients, $R O$ resection with no residual tumor, $S P$ spleen-preserving, $S R$ splenectomy

* Survival calculated only in subgroups, see Appendix B in Electronic supplementary material

pancreatectomy in several of the articles included both extended lymphadenectomy and direct invasion [16, 17, 37, $41,43,47,48]$. Margin status is a strong prognostic indicator in patients undergoing surgery for gastric cancer, and positive margins are associated with decreased survival [14, 42, 45]. Accordingly, resections of the spleen and/or 
pancreas in cases where direct invasion is suspected, in the absence of metastatic disease, may be treated with multivisceral resection [12, 14, 19, 42, 43, 45], though some argue that survival may not be improved with an aggressive surgical approach [21]. Importantly, it is clear that resection of the spleen and pancreas for direct invasion should be considered separately from extended lymphadenectomy with spleen and pancreas preservation.

Conclusions drawn from this review must consider the many limitations of the included studies. Most are retrospective case series from single institutions. The potential for publication bias exists as negative studies were not solicited. Furthermore, there may not be complete exclusion of patients who underwent splenectomy or distal pancreatectomy for indications other than lymphadenectomy, including locally invasive disease or secondary to surgical complications, such as bleeding.

\section{Conclusions}

Despite the concern about the increased mortality and morbidity of splenectomy and distal pancreatectomy during extended lymphadenectomy for gastric cancer as demonstrated in some studies, more contemporary studies demonstrate that this procedure can still be done safely with low short-term morbidity and mortality for patients undergoing curative surgery for gastric cancer. However, evidence from RCTs demonstrates no difference in the long-term, overall 5-year survival when patients undergo gastrectomy with spleen and pancreas preserving extended lymphadenectomy. Therefore, there is no compelling evidence that even in the face of a center's expertise to safely perform splenectomy and/or distal pancreatectomy during curative intent surgery for gastric cancer, this additional procedure benefits patients in the long-term. Future studies may refine a set of selection criteria for the patients who may benefit from splenectomy and/or distal pancreatectomy. Results from a large, multi-institution Japanese RCT that may ultimately answer this question are pending.

Acknowledgments This research is funded by the Canadian Cancer Society (grant no. 019325). Dr. Coburn has received salary support for this work through the Ontario Ministry of Health and Long-Term Care Career Scientist Award. Dr. Law is supported by the Hanna Family Chair in Surgical Oncology.

\section{References}

1. Bonenkamp J, Songun I, Welvaart K, van de Velde C, Hermans J, Sasako M, et al. Randomised comparison of morbidity after D1 and D2 dissection for gastric cancer in 996 Dutch patients. Lancet. 1995;345:745-8.
2. Cuschieri A, Joypaul V, Fayers P, Cook P, Fielding J, Craven J, et al. Postoperative morbidity and mortality after D1 and D2 resections for gastric cancer: preliminary results of the MRC randomised controlled surgical trial. The Surgical Cooperative Group. Lancet. 1996;347:995-9.

3. McCulloch P, Niita ME, Kazi H, Gama Rodrigues J. Gastrectomy with extended lymphadenectomy for primary treatment of gastric cancer. Br J Surg. 2005;92:5-13.

4. Memon MA, Subramanya MS, Khan S, Hossain MB, Osland E, Memon B. Meta-analysis of D1 versus D2 gastrectomy for gastric adenocarcinoma. Ann Surg. 2011;253:900.

5. Tanizawa Y, Terashima M. Lymph node dissection in the resection of gastric cancer: review of existing evidence. Gastric Cancer. 2010;13:137-48.

6. Yang SH, Zhang YC, Yang KH, Li YP, He XD, Tian JH, et al. An evidence-based medicine review of lymphadenectomy extent for gastric cancer. Am J Surg. 2009;197:246-51.

7. Huang CM, Wang JB, Lu HS, Zheng CH, Li P, Xie JW, et al. Prognostic impact of splenectomy on advanced proximal gastric cancer with No. 10 lymph node metastasis. Chin Med J. 2009;122:2757-62.

8. Chikara K, Hiroshi S, Masato N, Hirotoshi A, Goro M, Hidetaka O. Indications for pancreaticosplenectomy in advanced gastric cancer. Hepatogastroenterology. 2001;48:908-12.

9. Kodera Y, Sasako M, Yamamoto S, Sano T, Nashimoto A, Kurita A. Identification of risk factors for the development of complications following extended and superextended lymphadenectomies for gastric cancer. Br J Surg. 2005;92:1103-9.

10. Yonemura Y, Wu CC, Fukushima N, Honda I, Bandou E, Kawamura T, et al. Randomized clinical trial of D2 and extended paraaortic lymphadenectomy in patients with gastric cancer. Int $\mathrm{J}$ Clin Oncol. 2008;13:132-7.

11. Otsuji E, Yamaguchi T, Sawai K, Okamoto K, Takahashi T. Total gastrectomy with simultaneous pancreaticosplenectomy or splenectomy in patients with advanced gastric carcinoma. Br J Cancer. 1999;79:1789.

12. Erturk S, Ersan Y, Cicek Y, Dogusoy G, Senocak M. Effect of simultaneous splenectomy on the survival of patients undergoing curative gastrectomy for proximal gastric carcinoma. Surg Today. 2003;33:254-8.

13. Saka M, Morita S, Fukagawa T, Katai H. Present and future status of gastric cancer surgery. Jpn J Clin Oncol. 2011;41:307.

14. Kasakura Y, Fujii M, Mochizuki F, Kochi M, Kaiga T. Is there a benefit of pancreaticosplenectomy with gastrectomy for advanced gastric cancer? Am J Surg. 2000;179:237-42.

15. Noguchi Y, Yamamoto Y, Morinaga S, Amano T, Yoshikawa T, Tsuburaya A, et al. Does pancreaticosplenectomy contribute to better survival? Hepatogastroenterology. 2002;49:1436-40.

16. Schmid A, Thybusch A, Kremer B, Henne-Bruns D. Differential effects of radical D2-lymphadenectomy and splenectomy in surgically treated gastric cancer patients. Hepatogastroenterology. 2000;47:579-85.

17. Takeuchi K, Tsuzuki Y, Ando T, Sekihara M, Hara T, Yoshikawa $\mathrm{M}$, et al. Total gastrectomy with distal pancreatectomy and splenectomy for advanced gastric cancer. J Surg Res. 2001;101: 196-201.

18. Yamamoto M, Baba H, Kakeji Y, Endo K, Ikeda Y, Toh Y, et al. Postoperative morbidity/mortality and survival rates after total gastrectomy, with splenectomy/pancreaticosplenectomy for patients with advanced gastric cancer. Hepatogastroenterology. 2001;51:298-302.

19. Ohno M, Nakamura T, Ajiki T, Horiuchi H, Tabuchi Y, Kuroda Y. Procedure for lymph node dissection around splenic artery in proximal gastric cancer. Hepatogastroenterology. 2003;50:1173-7.

20. Sakaguchi T, Sawada H, Yamada Y, Fujimoto H, Emoto K, Takayama $\mathrm{T}$, et al. Indication of splenectomy for gastric 
carcinoma involving the proximal part of the stomach. Hepatogastroenterology. 2001;48:603-5.

21. Kitamura K, Nishida S, Ichikawa D, Taniguchi H, Hagiwara A, Yamaguchi $\mathrm{T}$, et al. No survival benefit from combined pancreaticosplenectomy and total gastrectomy for gastric cancer. $\mathrm{Br} \mathbf{~}$ Surg. 1999;86:119-22.

22. Sasada S, Ninomiya M, Nishizaki M, Harano M, Ojima Y, Matsukawa $\mathrm{H}$, et al. Frequency of lymph node metastasis to the splenic hilus and effect of splenectomy in proximal gastric cancer. Anticancer Res. 2009;29:3347.

23. Wang JY, Huang TJ, Chen FM, Huang CJ, Huang YS, Hsieh JS. A comparative study of pancreatectomy and pancreas-preserving gastrectomy in advanced gastric carcinomas. Hepatogastroenterology. 2004;51:1229-32.

24. Songun I, Putter H, Kranenbarg EMK, Sasako M, van de Velde CJH. Surgical treatment of gastric cancer: 15-year follow-up results of the randomised nationwide Dutch D1D2 trial. Lancet Oncol. 2010;11:439-49.

25. Cuschieri A, Weeden S, Fielding J, Bancewicz J, Craven J, Joypaul V, et al. Patient survival after D 1 and D 2 resections for gastric cancer: long-term results of the MRC randomized surgical trial. Br J Cancer. 1999;79:1522.

26. Csendes A, Burdiles P, Rojas J, Braghetto I, Diaz JC, Maluenda F. A prospective randomized study comparing D2 total gastrectomy versus D2 total gastrectomy plus splenectomy in 187 patients with gastric carcinoma. Surgery. 2002;131:401-7.

27. Furukawa $H$, Hiratsuka $M$, Ishikawa O, Ikeda $M$, Imamura $H$, Masutani S, et al. Total gastrectomy with dissection of lymph nodes along the splenic artery: a pancreas-preserving method. Ann Surg Oncol. 2000;7:669-73.

28. Yu W, Choi G, Chung H. Randomized clinical trial of splenectomy versus splenic preservation in patients with proximal gastric cancer. Br J Surg. 2006;93:559-63.

29. Fatouros M, Roukos DH, Lorenz M, Arampatzis I, Hottentrott C, Encke A, et al. Impact of spleen preservation in patients with gastric cancer. Anticancer Res. 2005;25:3023.

30. Okinaga $K$, Iinuma $H$, Kitamura $Y$, Yokohata $T$, Inaba $T$, Fukushima R. Effect of immunotherapy and spleen preservation on immunological function in patients with gastric cancer. J Exp Clin Cancer Res. 2006;25:341.

31. Japanese Gastric Cancer Association. Japanese gastric cancer treatment guidelines 2010 (ver. 3). Gastric Cancer 2011;14: 113-123.

32. Degiuli M, Sasako M, Calgaro M, Garino M, Rebecchi F, Mineccia M, et al. Morbidity and mortality after D1 and D2 gastrectomy for cancer: interim analysis of the Italian Gastric Cancer Study Group (IGCSG) randomised surgical trial. Eur J Surg Oncol (EJSO). 2004;30:303-8.

33. Jadad AR, Moore RA, Carroll D, Jenkinson C, Reynolds DJM, Gavaghan DJ, et al. Assessing the quality of reports of randomized clinical trials: is blinding necessary? Control Clin Trials. 1996;17:1-12.

34. Edwards P, Blackshaw G, Lewis W, Barry J, Allison M, Jones D. Prospective comparison of D1 vs modified D2 gastrectomy for carcinoma. Br J Cancer. 2004;90:1888-92.

35. Wu C, Hsiung C, Lo S, Hsieh M, Shia L, Whang Peng J. Randomized clinical trial of morbidity after D1 and D3 surgery for gastric cancer. Br J Surg. 2004;91:283-7.

36. Gorbunov E, Wechsler J, Stašek T, Tomin A, Solodun L. Significant prognostic factors in 283 patients after surgery for adenocarcinoma of the stomach. Scripta Medica (Brno). 2005;78:3-16.
37. Qin H, Lin C. Radical resection of gastric carcinoma with pancreas and spleen preservation a nd functional cleaning of lymph nodes. Chin Med J. 2002;115:736-9.

38. Kikuchi S, Nemoto Y, Natsuya K, Sakuramoto S, Kobayashi N, Shimao $\mathrm{H}$, et al. Which patients with advanced, proximal gastric cancer benefit from complete clearance of spleno-pancreatic lymph nodes? Anticancer Res. 2002;22:3513-7.

39. Lee KY, Noh SH, Hyung WJ, Lee JH, Lah KH, Choi SH, et al. Impact of splenectomy for lymph node dissection on long-term surgical outcome in gastric cancer. Ann Surg Oncol. 2001;8: 402-6.

40. Li C, Kim S, Lai J, Oh S, Hyung W, Choi W, et al. Lymph node dissection around the splenic artery and hilum in advanced middle third gastric carcinoma. Eur J Surg Oncol (EJSO). 2009;35:709-14.

41. Lo SS, Wu CW, Shen KH, Hsieh MC, Lui WY. Higher morbidity and mortality after combined total gastrectomy and pancreaticosplenectomy for gastric cancer. World J Surg. 2002;26:678-82.

42. Maehara Y, Oiwa H, Tomisaki S, Sakaguchi Y, Watanabe A, Anai $\mathrm{H}$, et al. Prognosis and surgical treatment of gastric cancer invading the pancreas. Oncology. 2000;59:1-6.

43. Nanthakumaran S, Fernandes E, Thompson A, Rapson T, Gilbert F, Park K. Morbidity and mortality rates following gastric cancer surgery and contiguous organ removal, a population based study. Eur J Surg Oncol. 2005;31:1141-4.

44. Oh SJ, Hyung WJ, Li C, Song J, Kang W, Rha SY, et al. The effect of spleen preserving lymphadenectomy on surgical outcomes of locally advanced proximal gastric cancer. J Surg Oncol. 2009;99:275-80.

45. Piso P, Bellin T, Aselmann H, Bektas H, Schlitt H, Klempnauer J. Results of combined gastrectomy and pancreatic resection in patients with advanced primary gastric carcinoma. Dig Surg. 2000;19:281-5.

46. Saji S, Sakamoto J, Teramukai S, Kunieda K, Sugiyama Y, Ohashi Y, et al. Impact of splenectomy and immunochemotherapy on survival following gastrectomy for carcinoma: covariate interaction with immunosuppressive acidic protein, a serum marker for the host immune system. Surg Today. 1999;29: 504-10.

47. Shen JG, Cheong JH, Hyung WJ, Kim J, Choi SH, Noh SH. Adverse effect of splenectomy on recurrence in total gastrectomy cancer patients with perioperative transfusion. Am J Surg. 2006;192:301-5.

48. Shin SH, Jung H, Choi SH, An JY, Choi MG, Noh JH. Clinical significance of splenic hilar lymph node metastasis in proximal gastric cancer. Ann Surg Oncol. 2009;16:1304-9.

49. Toneri M, Mitsumoto Y, Shimabukuro M, Sunagawa T, Itagaki $\mathrm{T}$, Iida $\mathrm{S}$, et al. Prognosis of patients with gastric carcinoma treated in remote island hospitals in Japan: a multivariable analysis. Anticancer Res. 2006;26:3621.

50. Verlato G, Roviello F, Marchet A, Giacopuzzi S, Marrelli D, Nitti D. Indexes of surgical quality in gastric cancer surgery: experience of an Italian network. Ann Surg Oncol. 2009;16: 594-602.

51. Zhang $\mathrm{CH}$, Zhan WH, He YL, Chen C, Huang MJ, Cai SR. Spleen preservation in radical surgery for gastric cardia cancer. Ann Surg Oncol. 2007;14:1312-9.

52. Sano T, Yamamoto S, Sasako M. Randomized controlled trial to evaluate splenectomy in total gastrectomy for proximal gastric carcinoma: Japan clinical oncology group study JCOG 0110-MF. Jpn J Clin Oncol. 2002;32:363. 